\title{
Heat-Treated Wood Reinforced High Density Polyethylene Composites
}

\section{Kompoziti visoke gustoće na bazi polietilena ojačani toplinski modificiranim drvom}

\author{
Original scientific paper • Izvorni znanstveni rad \\ Received-prispjelo: 27. 11. 2019. \\ Accepted-prihvaćeno: 26. 5. 2021. \\ UDK: $630 * 861.032 ; 630 * 863$ \\ https://doi.org/10.5552/drvind.2021.1971
}

\author{
(C) 2021 by the author(s) \\ Licensee Faculty of Forestry and Wood Technology, University of Zagreb. \\ This article is an open access article distributed \\ under the terms and conditions of the \\ Creative Commons Attribution (CC BY) license.
}

\begin{abstract}
This study investigated the effect of untreated and heat-treated ash and black pine wood flour concentrations on the selected properties of high density polyethylene (HDPE) composites. HDPE and wood flour were used as thermoplastic matrix and filler, respectively. The blends of HDPE and wood flour were compounded using single screw extruder and test samples were prepared through injection molding. Mechanical properties like tensile strength (TS), tensile modulus (TM), elongation at break (EatB), flexural strength (FS), flexural modulus (FM) and impact strength (IS) of manufactured composites were determined. Wood flour concentrations have significantly increased density, FS, TM and FM and hardness of composites while reducing TS, EatB and IS. Heattreated ash and black pine flour reinforced HDPE composites had higher mechanical properties than untreated ones. Composites showed two main decomposition peaks; one coming from ash wood flour (353-370 $\left.{ }^{\circ} \mathrm{C}\right)$ and black pine wood flour $\left(373-376^{\circ} \mathrm{C}\right)$, the second one from HDPE degradation $\left(469-490^{\circ} \mathrm{C}\right)$. SEM images showed improved dispersion of heat-treated ash and black pine wood flour. The obtained results showed that both the untreated and heat-treated ash/black pine wood flour have an important potential in the manufacture of HDPE composites.
\end{abstract}

Keywords: HDPE; wood flour; thermal modification; heat treatment; polymer composite

SAŽETAK • U radu je opisano istraživanje utjecaja koncentracije drvnog brašna od nemodificiranog $i$ toplinski modificiranog drva jasena i crnog bora na odabrana svojstva kompozita visoke gustoće na bazi polietilena (HDPE). HDPE i drvno brašno upotrijebljeni su kao termoplastična matrica i punilo. Mješavine HDPE-a i drvnog brašna pripremljene su uz pomoć ekstrudera s jednim vijkom, a ispitni su uzorci izrađeni injekcijskim prešanjem. Istraživanjem su određena mehanička svojstva proizvedenih kompozita poput vlačne čvrstoće (FS), modula elastičnosti pri vlačnom ispitivanju (FM), istezanja pri lomu (EatB), čvrstoće na svijanje (FS), modula elastičnosti pri tlačnom ispitivanju (FM) i udarne čvrstoće (IS). Koncentracije drvnog brašna značajno su povećale gustoću, tvrdoću, FS, TM i FM, a smanjile TS, EatB i IS. HDPE kompoziti ojačani drvnim brašnom od toplinski modificiranog drva jasena i crnog bora imali su bolja mehanička svojstva od kompozita ojačanih drvnim brašnom od nemodificiranog drva jasena i crnog bora. Kompoziti su pokazali dva glavna područja razgradnje: prvo, razgradnju drvnog brašna drva ariša $\left(353-370{ }^{\circ} \mathrm{C}\right)$ i drvnog brašna drva crnog bora $\left(373-376{ }^{\circ} \mathrm{C}\right)$ te, drugo, razgradnju HDPE-a $\left(469-490^{\circ} \mathrm{C}\right)$. SEM slike potvrdile su poboljšanu raspodjelu drvnog brašna od toplinski modificiranog drva jasena i crnog bora. Rezultati su pokazali da drvno brašno od nemodificiranoga $i$ toplinski modificiranog drva jasena i crnog bora imaju velik potencijal u proizvodnji HDPE kompozita.

Ključne riječi: HDPE; drvno brašno; toplinska modifikacija; toplinski tretman; polimerni kompoziti

\footnotetext{
${ }^{1}$ Authors are researchers at Kahramanmaras Sutcu Imam University, Faculty of Forestry, Department of Forest Industrial Engineering, Kahramanmaras, Turkey.

${ }^{2}$ Authors are researchers at Bartin University, Faculty of Forestry, Department of Forest Industrial Engineering, Bartin, Turkey.
} 


\section{INTRODUCTION}

\section{UVOD}

Polymer composites can be manufactured using polymer matrix such as polyethylene, polystyrene, polypropylene and polyvinyl chloride and organic filler (wood fiber, wood flour and agricultural residues) or inorganic filler (talc, mica, calcium carbonate). Recently, the use of organic fillers has been increased due to many advantages such as low cost, low density, high specific properties, non-abrasive nature, renewability, biodegradability and availability. Therefore, several studies were conducted to manufacture polymer composites using organic fillers including wood flour, wheat straw, nutshell flour, sunflower stalk, flax, jute, sisal, bagasse, ramie and kapok (Yang et al., 2005; Mengeloglu and Karakus, 2008; Kaymakci et al., 2013; Donmez Cavdar et al., 2014; Aydemir et al., 2015). Some of the studies focused on industrial products and they have been applied in industrial fields such as outdoor furniture, automobile parts, structural panels, etc. Wood, as organic filler, is the most feasible material to produce the polymer composites. However, because of the moisture absorption in wood, as all organic fillers, it suffers a number of disadvantages. Poor resistance against fungal and insect attack, swelling, and shrinkage resulting from water absorption and desorption are some of these shortcomings. Many studies have been carried out to improve the unfavorable properties of wood (Kaboorani et al., 2008; Arwinfar et al., 2016). These include chemical and thermal modifications. Chemical modification of wood itself can be done, for example, by acetylation with acetic anhydride (Cetin and Ozmen, 2011; Ozmen et al., 2013), acetyl chloride, or isopropenyl acetate, which are usually coated on the surface of wood fibers. Others are chemical modifications such as surface treatments, corona or plasma discharge, and enzymatic treatment (Follrich et al., 2010; Aragal et al., 2012). The chemical modifications only provide an improvement on the surface of materials used and their outdoor performances are generally not good enough in application areas. Heat treatment of wood, called thermal modification, has been reported to be an effective method to provide a sustainable improvement of the physical properties such as dimensional stability and/or durability of wood. Many researchers have used heat treatment process to improve wood properties (Yildiz et al., 2006; Shi et al., 2007; Gunduz and Aydemir, 2009; Kabir et al., 2012; Segerholm, 2012; Li et al., 2013; Boruvka et al., 2015). Heat treatment of wood reduces hydrophilicity of wood. In addition, heat treatment modifies the polar nature of wood possibly resulting in better compatibility between wood and the polymer matrix, thus leading to high quality and thermally stable composites. The changes in wood chemistry can be utilized to improve compatibility between wood and the polymer matrix (Aragal et al., 2012). Some studies focused on the use of the heat-treated wood in the production of polymer composites (Aydemir et al., 2015; Kaboorani et al., 2008; Arwinfar et al., 2016; Kaboorani and Faezipour, 2009; Aydemir et al., 2019); however, the literature data on the properties of polymer composites with heat-treated wood is scarce.
The aim of this study was to evaluate the effect of heat-treated/untreated ash wood and black pine wood flour concentrations on the selected properties of high density polyethylene (HDPE) composites. Density, hardness, tensile strength, tensile modulus, elongation at break, flexural strength, flexural modulus and impact strength properties and thermogravimetric analyzer (TGA), scanning electron microscope (SEM) and Xray diffraction $(\mathrm{XRD})$ analysis were studied.

\section{MATERIALS AND METHODS}

\section{MATERIJALI I METODE}

\subsection{Materials}

2.1. Materijali

High density polyethylene (HDPE-I-668) was supplied by PETKIM Inc. in Turkey. HDPE has a density of $0.96 \mathrm{~g} / \mathrm{cm}^{3}$, melting point of $134{ }^{\circ} \mathrm{C}, \mathrm{MFI} / 230$ ${ }^{\circ} \mathrm{C} / 2.16 \mathrm{~kg}=0.36 \mathrm{~g} / 10 \mathrm{~min}$. Untreated and heat-treated (at $212^{\circ} \mathrm{C}$ for $3 \mathrm{~h}$ under water vapor) ash (Fraxinus excelsior L.) and black pine (Pinus nigra Arn.) woods were supplied from NovaWood Inc. in Turkey. The densities of untreated ash and black pine wood were $0.70 \mathrm{~g} / \mathrm{cm}^{3}$ and $0.50 \mathrm{~g} / \mathrm{cm}^{3}$ and after thermal treatment, the densities changed to $0.65 \mathrm{~g} / \mathrm{cm}^{3}$ and $0.47 \mathrm{~g} / \mathrm{cm}^{3}$, respectively. All wood types were grounded with a labtype grinder, and the size of the filler for both untreated and heat-treated wood flour was 80 mesh.

\subsection{Processing of polymer composite materials 2.2. Priprema kompozita}

The experimental design of the study is presented in Table 1. During the manufacturing process, depending on the formulation, the high density polyethylene (HDPE), untreated and heat-treated ash and black pine wood flours, as fillers, were mixed in a high intensity mixer to produce homogeneous blend. The blends were compounded in a laboratory scale single screw extruder (TTB, Tecnomatic Inc, Turkey) at $40 \mathrm{rpm}$ screw speed. Temperatures were set at $180{ }^{\circ} \mathrm{C}$ from feed zone to die zone. Extruded samples were collected, cooled and granulated into pellets. The pellets were then oven-dried at $80^{\circ} \mathrm{C}$ for $24 \mathrm{~h}$ and stored in sealed plastic bags for injection molding. The pellets were injection molded into tensile, flexural test samples using an HDX-88 injection molding machine at a barrel temperature of between $180{ }^{\circ} \mathrm{C}$ and $200{ }^{\circ} \mathrm{C}$ (injection pressure: 100 bar, injection speed: $80 \mathrm{~mm} /$ sec., screw speed: $40 \mathrm{rpm}$, cooling time about $30 \mathrm{~s}$ ).

\subsection{Density}

\subsection{Gustoća}

Density of the manufactured polymer composites were determined using water displacement technique and analyzed utilizing central composite design (CCD) (ASTM D792-13).

\subsection{Mechanical properties}

\subsection{Mehanička svojstva}

To evaluate the effect of heat-treated and untreated wood flours on the mechanical, thermal and morphological properties of HDPE composites, testing of 
..... Karakuş, Aydemir, Gunduz, Mengeloğlu: Heat-Treated Wood Reinforced High Density...

Table 1 Experiment design

Tablica 1. Plan eksperimenta

\begin{tabular}{|c|c|c|c|c|c|}
\hline \multirow{2}{*}{ ID } & \multirow{2}{*}{$\begin{array}{c}\text { HDPE, } \\
\%\end{array}$} & \multicolumn{2}{|c|}{$\begin{array}{c}\text { Untreated wood flour, } \% \\
\text { Nemodificirano drvno brašno, \% }\end{array}$} & \multicolumn{2}{|c|}{$\begin{array}{c}\text { Heat-treated wood flour, \% } \\
\text { Toplinski modificirano drvno brašno, \% }\end{array}$} \\
\hline & & $\begin{array}{c}\text { Ash wood } \\
\text { Drvo jasena }\end{array}$ & $\begin{array}{l}\text { Black pine wood } \\
\text { Drvo crnog bora }\end{array}$ & $\begin{array}{c}\text { Ash wood } \\
\text { Drvo jasena }\end{array}$ & $\begin{array}{l}\text { Black pine wood } \\
\text { Drvo crnog bora }\end{array}$ \\
\hline $\begin{array}{l}\text { Control } \\
\text { Kontrolni uzorci }\end{array}$ & 100 & & & & \\
\hline UAC1 & 90 & 10 & & & \\
\hline UAC2 & 80 & 20 & & & \\
\hline UAC3 & 70 & 30 & & & \\
\hline TAC1 & 90 & & & 10 & \\
\hline TAC2 & 80 & & & 20 & \\
\hline TAC3 & 70 & & & 30 & \\
\hline UBPC1 & 90 & & 10 & & \\
\hline UBPC2 & 80 & & 20 & & \\
\hline UBPC3 & 70 & & 30 & & \\
\hline TBPC1 & 90 & & & & 10 \\
\hline TBPC2 & 80 & & & & 20 \\
\hline TBPC3 & 70 & & & & 30 \\
\hline
\end{tabular}

the flexural, tensile and notched impact properties were conducted in a climate-controlled testing laboratory. Flexural properties such as flexure strength $(F S)$ and flexure modulus $(F M)$ were determined in accordance with ASTM D 790. The flexural specimens $(4 \times 15 \times 160$ $\mathrm{mm}$ ) with $80 \mathrm{~mm}$ span length were tested in the three points loading with a crosshead speed of $2 \mathrm{~mm} / \mathrm{min}$ on a Zwick Roell Z010 Universal testing machine. The same instrument was also used for the tensile testing. Tensile properties, such as tensile strength $(T S)$ and tensile modulus (TM), were conducted according to ASTM D 638. Samples $(4 \mathrm{~mm} \times 18.6 \mathrm{~mm} \times 165 \mathrm{~mm})$ were tested at a crosshead speed of $5 \mathrm{~mm} / \mathrm{min}$. The tensile modulus of the samples was taken as the slope of the curve at stress levels between $0.05 \%$ and $0.2 \%$. Notched impact tests (sample dimension was $4 \mathrm{~mm} \times$ $15 \mathrm{~mm} \times 50 \mathrm{~mm}$ ) were performed according to ASTM D 256. The notches were added using a Polytest notching cutter by RayRan and notched samples were tested on a HIT5.5P impact testing machine, manufactured by Zwick. Six specimens prepared according to the applicable standards were used in all mechanical testing.

\subsection{Hardness}

\subsection{Tvrdoća}

Inspired by the Shore-D method, the hardness property of specimens was tested according to ASTM D 2240. Six specimens with dimension of $50 \mathrm{~mm} \times 13$ $\mathrm{mm} \times 5 \mathrm{~mm}$ were tested for each composite formulation.

\subsection{Thermogravimetric analysis (TGA)}

2.6. Termogravimetrijska analiza (TGA)

Thermogravimetric analysis (TGA) measurements were carried out using Shimadzu TGA-50 on samples of about $10 \mathrm{mg}$. Each sample was scanned over a temperature range from room temperature to $700{ }^{\circ} \mathrm{C}$ at a heating rate of $10{ }^{\circ} \mathrm{C} / \mathrm{min}$ under nitrogen with a flow rate of $20 \mathrm{ml} / \mathrm{min}$ to avoid sample oxidation. Three samples randomly picked from the ground test specimens were used.

\subsection{Scanning electron microscope (SEM) analysis} 2.7. Pretražna elektronska mikroskopija (SEM)

The fractured surface of the samples was also studied by using Tescan MAIA3 XMU scanning electron microscope. All SEM characterization was conducted on the fractured section of the tensile test samples. The samples were first dipped into liquid nitrogen and snapped to half to prepare the fractured surfaces.

\subsection{X-ray diffraction (XRD)}

2.8. Rendgenska difrakcija (XRD)

XRD was performed with a high resolution Xray diffractometer (Model XPert PRO, Philips PANalytical, Netherlands) with Ni-filtered $\mathrm{Cu} \mathrm{Ka}$ (1.540562 $\AA$ ) radiation source operated at $45 \mathrm{kV}$ voltage and 40 $\mathrm{mA}$ electric current. The samples were scanned from $5^{\circ}$ to $40^{\circ} 2 \theta$ range with a step of $0.02^{\circ}$ and a step time of $2.5 \mathrm{~s}$. A silicon zero-background plate was used to make sure there was no peak associated with the sample holder. The same sample holder and the same position of the holder were used for all tests. The crystallinity index $(C I)$ of the powdered samples was calculated as the ratio of the total area under the resolved crystalline peaks to the total area under the unresolved X-ray scattering curve (Rabiej, 2003). Three specimens for each test were scanned with XRD. CI values were found using Eq. 1:

$$
C I(\%)=\frac{\sum A_{\mathrm{c}}}{\sum\left(A_{\mathrm{c}}+A_{\mathrm{a}}\right)}
$$

Where $A_{\mathrm{c}}$ is the integrated area underneath the respective crystalline peaks, and $A_{\mathrm{a}}$ is the integrated area of the amorphous halo.

\subsection{Statistical analysis}

2.9. Statistička analiza

Design-Expert ${ }^{\circ}$ Version 7.0.3 statistical software program was used for statistical analysis. The effects of wood concentration on the physical, mechanical, thermal and morphological properties of the 
obtained samples were evaluated. All samples were analyzed with the one-way variance analysis (ANOVA), and then Duncan test was applied to determine whether the samples differed significantly among the groups. All statistical analysis was conducted at $99 \%$ significance level $(p<0.01)$.

\section{RESULTS AND DISCUSSION}

3. REZULTATI I RASPRAVA

\subsection{Densities, hardness (Shore D) and mechanical properties}

3.1. Gustoća, tvrdoća (Shore D) i mehanička svojstva

Densities in the range of $0.87-0.93 \mathrm{~g} / \mathrm{cm}^{3}$ were measured based on heat-treated/untreated ash wood flour concentrations in polymer composites. Density variations in HDPE composites are presented in Table 2. Density of polymer composites manufactured with the addition of $10 \%$ ash wood flour was decreased. Density of the ash wood flour reinforced HDPE composites was increased with the other wood concentrations. However, the increases in the density of the composites were found to be not statistically significant and their densities exhibited similar results.

Densities in the range of $0.87-0.93 \mathrm{~g} / \mathrm{cm}^{3}$ were measured based on heat-treated/untreated black pine wood concentrations in polymer composites. The densities of black pine wood reinforced HDPE composites, similar to density of ash wood flour reinforced HDPE composites, were firstly decreased with the addition of $10 \%$ black pine wood but then were increased with the addition of other wood concentrations. Compared to heat-treated and untreated black pine wood, densities of the composites were found to have similar results. Wood flour is a compressible material and the density of the wood cell wall is about $1.44-1.50 \mathrm{~g} / \mathrm{cm}^{3}$ (Kellog, 1981). The porous anatomy of the solid wood results in overall densities of about 0.32-0.72 $\mathrm{g} / \mathrm{cm}^{3}$, when dry (Simpson and TenWolde, 1999). However, the high pressures found during plastics processing can collapse the hollow fibers that comprise the wood flour or fill them with the molecular weight additives and polymers. Consequently, adding wood fibers to commodity plastics increases their density (Simpson and TenWolde, 1999). Increased density of the thermoplastic composites with lignocellulosic filler was also reported by Rosa et al. (2009).

The effect of both heat-treated/untreated wood and wood concentration on the hardness (Shore D) of wood reinforced HDPE composites is shown in Table 2 . The results showed that hardness of polymer composites manufactured with the addition of $10 \%$ heattreated/untreated ash wood flour was decreased but the addition of other wood concentration did not provide a significant change in the hardness of HDPE composites. It is believed that hardness properties of wood reinforced HDPE composites decreased due to density of

Table 2 Duncan test results and standard deviation of density, hardness (shore D) and mechanical properties of neat HDPE and composites

Tablica 2. Rezultati Duncanova testa i standardne devijacije gustoće, tvrdoće (Shore D) i mehaničkih svojstava čistog HDPE-a i kompozita

\begin{tabular}{|c|c|c|c|c|c|c|c|c|}
\hline $\begin{array}{l}\text { Samples } \\
\text { Uzorci }\end{array}$ & $d, \mathrm{~g} / \mathrm{cm}^{3}$ & Shore-D & $T S, \mathrm{MPa}$ & $T M, \mathrm{MPa}$ & $E a t B, \%$ & $F S, \mathrm{MPa}$ & $F M, \mathrm{MPa}$ & $I S, \mathbf{k J} / \mathbf{m}$ \\
\hline $\begin{array}{l}\text { Control } \\
\text { Kontrolni } \\
\text { uzorci }\end{array}$ & $\begin{array}{c}0.93 \mathrm{~A} \\
( \pm 0.1)\end{array}$ & $65 \mathrm{AB}( \pm 2)$ & $20 \mathrm{D}( \pm 0.1)$ & $580 \mathrm{~F}( \pm 12)$ & $460 \mathrm{~F}( \pm 2)$ & $40 \mathrm{G}( \pm 0.2)$ & $\begin{array}{c}1750 \mathrm{G} \\
( \pm 22)\end{array}$ & $\begin{array}{c}5 \mathrm{G} \\
( \pm 0.5)\end{array}$ \\
\hline UAC1 & $\begin{array}{l}0.87 \mathrm{~A} \\
( \pm 0.1)\end{array}$ & $63 \mathrm{~A}( \pm 1)$ & $20 \mathrm{D}( \pm 0.2)$ & $\begin{array}{c}429 \mathrm{AB} \\
( \pm 19)\end{array}$ & $34 \mathrm{D}( \pm 9)$ & $\begin{array}{l}30 \mathrm{AB} \\
( \pm 0.5)\end{array}$ & $996 \mathrm{~A}( \pm 35)$ & $15 \mathrm{~F}( \pm 0.7)$ \\
\hline UAC2 & $\begin{array}{l}0.90 \mathrm{~A} \\
( \pm 0.1)\end{array}$ & $65 \mathrm{AB}( \pm 3)$ & $19 \mathrm{~B}( \pm 0.3)$ & $\begin{array}{c}452 \mathrm{AB} \\
( \pm 18)\end{array}$ & $18 \mathrm{C}( \pm 4)$ & $32 \mathrm{D}( \pm 0.5)$ & $\begin{array}{c}1186 \mathrm{~B} \\
( \pm 10)\end{array}$ & $12 \mathrm{D}( \pm 0.6)$ \\
\hline UAC3 & $\begin{array}{l}0.92 \mathrm{~A} \\
( \pm 0.1)\end{array}$ & 66 B $( \pm 6)$ & $18 \mathrm{~A}( \pm 0.3)$ & $\begin{array}{c}513 \mathrm{CD} \\
( \pm 28)\end{array}$ & $10 \mathrm{~A}( \pm 1)$ & $34 \mathrm{E}( \pm 0.6)$ & $\begin{array}{c}1359 \mathrm{D} \\
( \pm 54)\end{array}$ & $10 \mathrm{C}( \pm 0.7)$ \\
\hline TAC1 & $\begin{array}{l}0.88 \mathrm{~A} \\
( \pm 0.1)\end{array}$ & $63 \mathrm{~A}( \pm 1)$ & $22 \mathrm{~F}( \pm 0.2)$ & 458B $( \pm 11)$ & $33 \mathrm{D}( \pm 5)$ & $31 \mathrm{C}( \pm 0.6)$ & $\begin{array}{c}1136 \mathrm{~B} \\
( \pm 33)\end{array}$ & $12 \mathrm{D}( \pm 0.8)$ \\
\hline TAC2 & $\begin{array}{l}0.91 \mathrm{~A} \\
( \pm 0.1)\end{array}$ & 65 B $( \pm 5)$ & $22 \mathrm{~F}( \pm 0.3)$ & $524 \mathrm{D}( \pm 14)$ & $12 \mathrm{AB}( \pm 2)$ & $35 \mathrm{~F}( \pm 0.2)$ & $\begin{array}{c}1470 \mathrm{E} \\
( \pm 22)\end{array}$ & $\begin{array}{c}9 \mathrm{C} \\
( \pm 0.2) \\
\end{array}$ \\
\hline TAC3 & $\begin{array}{l}0.92 \mathrm{~A} \\
( \pm 0.1)\end{array}$ & $65 \mathrm{~B}( \pm 3)$ & $21 \mathrm{EF}( \pm 0.2)$ & $594 \mathrm{E}( \pm 34)$ & $\begin{array}{l}9 \mathrm{~A} \\
( \pm 1)\end{array}$ & $39 \mathrm{G}( \pm 1.4)$ & $\begin{array}{c}1726 \mathrm{G} \\
( \pm 39)\end{array}$ & $\begin{array}{c}8 \mathrm{~B} \\
( \pm 0.5)\end{array}$ \\
\hline UBPC1 & $\begin{array}{l}0.87 \mathrm{~A} \\
( \pm 0.1)\end{array}$ & $63 \mathrm{~A}( \pm 1)$ & $\begin{array}{l}21 \mathrm{EF} \\
( \pm 0.1)\end{array}$ & $422 \mathrm{~A}( \pm 19)$ & $33 \mathrm{D}( \pm 6)$ & $30 \mathrm{~A}( \pm 0.6)$ & $\begin{array}{c}1058 \mathrm{~A} \\
( \pm 40)\end{array}$ & $16 \mathrm{~F}( \pm 0.8)$ \\
\hline UBPC2 & $\begin{array}{l}0.89 \mathrm{~A} \\
( \pm 0.1)\end{array}$ & $65 \mathrm{~B}( \pm 4)$ & $20 \mathrm{D}( \pm 0.1)$ & $\begin{array}{c}455 \mathrm{AB} \\
( \pm 24)\end{array}$ & $19 \mathrm{C}( \pm 3)$ & $\begin{array}{l}30 \mathrm{BC} \\
( \pm 0.7)\end{array}$ & $\begin{array}{c}1137 \mathrm{~B} \\
( \pm 50)\end{array}$ & $13 \mathrm{E}( \pm 0.5)$ \\
\hline UBPC3 & $\begin{array}{l}0.93 \mathrm{~A} \\
( \pm 0.1)\end{array}$ & $67 \mathrm{C}( \pm 6)$ & $19 \mathrm{C}( \pm 0.2)$ & $575 \mathrm{E}( \pm 43)$ & $\begin{array}{l}8 \mathrm{~A} \\
( \pm 1)\end{array}$ & $35 \mathrm{~F}( \pm 0.4)$ & $\begin{array}{l}1604 \mathrm{~F} \\
( \pm 81)\end{array}$ & $10 \mathrm{C}( \pm 0.9)$ \\
\hline TBPC1 & $\begin{array}{l}0.87 \mathrm{~A} \\
( \pm 0.1)\end{array}$ & $64 \mathrm{~A}( \pm 3)$ & $21 \mathrm{E}( \pm 0.1)$ & $\begin{array}{c}448 \mathrm{AB} \\
( \pm 14)\end{array}$ & $42 \mathrm{E}( \pm 5)$ & $29 \mathrm{~A}( \pm 0.3)$ & $\begin{array}{c}1020 \mathrm{~A} \\
( \pm 12)\end{array}$ & $12 \mathrm{D}( \pm 0.4)$ \\
\hline ТВРC2 & $\begin{array}{l}0.90 \mathrm{~A} \\
( \pm 0.1)\end{array}$ & $65 \mathrm{~B}( \pm 2)$ & $20 \mathrm{D}( \pm 0.2)$ & $490 \mathrm{C}( \pm 21)$ & $16 \mathrm{BC}( \pm 2)$ & $33 \mathrm{D}( \pm 0.1)$ & $\begin{array}{c}1261 \mathrm{C} \\
( \pm 26)\end{array}$ & $\begin{array}{c}9 \mathrm{C} \\
( \pm 0.7) \\
\end{array}$ \\
\hline ТВРC3 & $\begin{array}{l}0.93 \mathrm{~A} \\
( \pm 0.1)\end{array}$ & $67 \mathrm{C}( \pm 9)$ & $19 \mathrm{~B}( \pm 0.1)$ & $566 \mathrm{E}( \pm 29)$ & $\begin{array}{l}8 \mathrm{~A} \\
( \pm 1)\end{array}$ & $36 \mathrm{~F}( \pm 0.2)$ & $\begin{array}{c}1623 \mathrm{~F} \\
( \pm 26)\end{array}$ & $\begin{array}{c}7 \mathrm{~A} \\
( \pm 0.3) \\
\end{array}$ \\
\hline
\end{tabular}


polymer composites manufactured with the addition of $10 \%$ wood flour. The lowest and highest hardness was determined as about 63 for the UAC1, TAC1, UBPC1 and TBPC1 and as 67 for the TBPC 3, respectively. The hardness of HDPE composites showed that the filler concentration has a more important impact than heat treatment. Heat-treated ash and black pine wood flour reinforced HDPE composites had a positive effect on hardness. Consequently, the heat treatment did not provide any improvement to the hardness with the filler concentration of $10 \%$ and $30 \%$. Similar results for wood reinforced polymer composites were also observed by Hua et al. (2011), Kord (2011), Medupin et al. (2013) and Sathishkumar (2014).

The obtained data for the TS of neat HDPE and the composites are presented in Table 2. Tensile strength (TS) of HDPE composites manufactured using untreated ash wood flour was $20 \mathrm{MPa}, 20 \mathrm{MPa}, 19$ $\mathrm{MPa}$ and $18 \mathrm{MPa}$ for $0 \%, 10 \%, 20 \%$ and $30 \%$ wood concentration, respectively. Adding untreated ash did not provide a significant increase in the tensile strength of HDPE composites and the tensile strength of HDPE composites was reduced by untreated ash wood flour concentration $(p<0.01)$. This reduction might be caused by the poor adhesion between hydrophilic filler wood and hydrophobic PE matrix. Reduced TS values due to the lack of compatibility between filler and polymer were also reported by others (Alsewailem and Binkhder, 2014; Obasi, 2015). The addition of heat-treated ash wood flour into neat HDPE generally improved the tensile strength $(p<0.01)$. In the studied heat-treated wood concentration range, the addition of more heattreated wood into HDPE composites provided higher $T S$ values as compared to composites manufactured with untreated ash wood. Arwinfar et al. (2016) also reported that the addition of heat-treated wood into polymer matrix increased tensile strength. Tensile strength (TS) of HDPE composites manufactured using untreated black pine wood was $20 \mathrm{MPa}, 21 \mathrm{MPa}, 20$ $\mathrm{MPa}$ and $19 \mathrm{MPa}$ for $0 \%, 10 \%, 20 \%$ and $30 \%$ wood concentration, respectively (Table 2). The tensile strength of HDPE composites manufactured with the addition of $10 \%$ heat-treated/untreated black pine wood was increased but the addition of more wood concentration into HDPE matrix did not provide any improvement in TS. It is believed that tensile properties of wood reinforced HDPE composites was decreased due to density of polymer composites manufactured with the addition of $10 \%$ wood flour. Similar results were also reported by Robin and Breton (2001). It can be said that wood species exhibited a different effect on the tensile strength of the polymer composites. However, adding untreated ash and black pine wood flour did not provide a significant improvement in the similar tensile strength. Tensile strength of untreated and heat-treated black pine wood reinforced composites generally exhibited similar results and it can be said that both heat-treated and untreated black pine wood did not have a significant effect on the tensile strength.

In the case of tensile modulus (TM), adding untreated and heat-treated wood flour to neat HDPE gen- erally has not a significant effect on $T M$, and $T M$ of all HDPE composites was lower than neat HDPE expected for TAC3; TM of HDPE composites was significantly increased while heat-treated and untreated ash wood flour concentration was increased from $10 \%$ to $30 \%$ $(p<0.01)$. The obtained data for TM of ash wood flour reinforced HDPE composites is presented in Table 2. HDPE composites manufactured using heat-treated ash wood flour showed higher TM than untreated ash wood flour. Heat-treated ash wood flour had a positive effect on $T M$. Similar to $T M$ of ash wood flour reinforced HDPE composites, $T M$ was significantly increased by untreated and heat-treated black pine wood concentration $(p<0.01)$. Heat-treated black pine wood reinforced composite showed higher TM than untreated ones. Wood species did not have a significant effect on the tensile modulus of the composites and TM of all HDPE composites was found to be lower than its neat HDPE. In conclusion, the $T M$ of HDPE composite reinforced with both heat-treated/untreated ash and black pine wood flours was increased with wood concentrations. Similar results were also reported by Robin and Breton (2014) and Kaboorani et al. (2008).

The results for elongation at break (EatB) values can be seen in Table 2. Both ash and black pine wood flour concentrations had a negative effect on EatB of HDPE polymer composites $(p<0.01)$, respectively and $E a t B$ values were generally reduced with the increased concentration of ash and black pine wood flour due to increasing stiffness of the composites. As a result, the elongation at break values reduced with adding both untreated and heat-treated wood flour. The elongation at break decreased from $460 \%$ to $10 \%$ and $9 \%$ for untreated and heat-treated ash wood flour concentration, and $8 \%$ for untreated and heat-treated black pine wood flour, increasing from 0 to $30 \mathrm{wt} \%$ in neat HDPE, respectively. Usually in the composites, lower elongation at break values was observed with increased modulus (Mengeloglu and Karakus, 2008 and 2008a).

The results of the flexural strength $(F S)$ are presented in Table 2. The FS values of HDPE polymer composites were significantly increased by untreated and heat-treated ash wood flour concentration $(\mathrm{p}<0.01)$, but the $T M$ of all composites was found to be lower than its neat HDPE. HDPE composites manufactured using heat-treated ash wood flour generally showed higher FS than when using untreated ash wood flour. Adding heat-treated ash wood flour generally had a positive effect on $F S$. Similar to $F S$ of ash wood flour reinforced HDPE composites, FS was significantly increased by heat-treated and untreated black pine wood concentration $(p<0.01)$, but the $F S$ of all composites was found to be lower than its neat HDPE. Heat-treated black pine wood reinforced composites generally provided higher $F S$ than the composites with untreated ones, and FS values of all HDPE composites were found to be similar to each other. The addition of heattreated wood flour in composites had a positive effect on $F S$, but the addition of untreated and heat-treated wood flour did not improve $F S$ of neat HDPE, and all $F S$ values of the composites were found to be lower 
than $F S$ of neat HDPE. Wood species generally did not have a significant effect on the FS of HDPE composites. As a result, the $F S$ of HDPE composite reinforced with both heat-treated/untreated ash and black pine wood flour was increased with wood concentrations. Composites produced with $30 \%$ heat-treated ash and black pine wood flour provided significantly higher $F S$ values compared to other composites. In previous studies, the effects of different lignocellulosic fillers on selected properties of polymer composites were investigated and it is reported that flexural strength of the polymer composites was increased with increasing lignocellulosic filler content (Kiziltas et al., 2014; Donmez Cavdar et al., 2015). For polyolefin-based plastic lumber decking boards, ASTM D 6662 (2001) standard requires the minimum $F S$ of $6.9 \mathrm{MPa}(1.000$ psi). All composites produced in this study provided $F S$ values (29.68-33.87 MPa and 31.12-38.59 MPa) for heat-treated and untreated ash wood flour, respectively, and (29.52-35.24 MPa and 29.36-35.57 MPa) for untreated and heat-treated black pine wood, respectively, that are well over the requirement by the standard.

A similar trend in $F S$ was observed for flexural modulus $(F M)$ as shown in Table 2. Both heat-treated and untreated ash and black pine wood flour concentration had a significant effect on FM of HDPE composites $(p<0.01$ and $p<0.01$, respectively). The presence of both untreated/heat-treated ash and black pine wood flour improved $F M$ values, however $F M$ values of all HDPE composites were found to be lower than $F M$ of neat HDPE. ASTM D 6662 (2001) standard requires the minimum $F M$ of $340 \mathrm{MPa}$ (50.000 psi) for polyolefin-based plastic lumber decking boards. All composites produced in this study provided FM values of 996$1359 \mathrm{MPa}$ and 1136-1726 $\mathrm{MPa}$ for untreated and heat-treated ash wood flour, respectively, and 1058$1604 \mathrm{MPa}$ and 1020-1623 MPa for untreated and heattreated black pine wood, respectively. These values are well over the required standards.

The results for impact strength $(I S)$ are presented in Table 2. The results showed that IS of the composites manufactured with the addition of $10 \%$ heat-treated/untreated ash and black pine wood flour was increased, but it was decreased with the addition of more wood concentration into neat HDPE. Both untreated/heat-treated ash and black pine wood flour concentration had a significant effect on IS of HDPE composites $(p<0.01)$. Generally, with the rise of both untreated/heat-treated ash and black pine wood flour concentration, IS values were decreased. HDPE polymer composites manufactured using untreated ash and black flour pine wood showed higher IS than heat-treated ones. Similar results were also reported by Aydemir et al. (2015) and Huang et al. (2012). They found that the increase in IS occurred because adding wood flour played an important role in strengthening and enhanced two-phase interface area interaction of the composite. However, while wood flour concentrations increased, interface compatibility was a major problem. Thus, impact strength of the wood polymer composites was found to decrease by Huang et al. (2012) and Tisserat et al. (2013). Boonstra et al. (2007) found that heat treatment decreases the impact strength of the wood due to the significantly lower density of the treated specimens, and therefore it can be said that neither heat treatment nor wood flour concentration have a significant effect on the impact strength of HDPE composites.

\subsection{Thermal and morphological properties of wood reinforced HDPE composites \\ 3.2. Toplinska i morfološka svojstva drvom ojačanih HDPE kompozita}

The curves for thermogravimetric analysis (TGA) and differential thermogravimetry (DTG) of HDPE composites manufactured using untreated/heattreated ash and black pine wood flour are presented in Figure 1. The summary of thermal stability for neat HDPE, the composites with $30 \%$ untreated ash wood flour (UAC3) and heat-treated ash wood flour (TAC3), and the composites with $30 \%$ untreated black pine wood flour (UBPC3) and heat-treated black pine wood flour (TBPC3) are given in Table 3. Neat HDPE showed single stage degradation at the set temperature of $469^{\circ} \mathrm{C}$ and total mass loss of $99 \%$. The TGA curves of the wood exhibit two mass loss peaks (Yang et al., 2005; Karakus et al., 2016). The first occurs at about $100{ }^{\circ} \mathrm{C}$ and is mainly caused by evaporation of moisture and other volatiles from the wood. The second peak, at approximately $200{ }^{\circ} \mathrm{C}$ to $400{ }^{\circ} \mathrm{C}$, is due to the degradation of hemicelluloses, cellulose, and lignin. Hemicellulose degrades between $150{ }^{\circ} \mathrm{C}$ and $350{ }^{\circ} \mathrm{C}$, cellulose decomposes between $240{ }^{\circ} \mathrm{C}$ and $350{ }^{\circ} \mathrm{C}$, and lignin between $250{ }^{\circ} \mathrm{C}$ and $500{ }^{\circ} \mathrm{C}$ (Kaboorani and Faezipour, 2009; Byren and Nagle, 1997). HDPE composites provided two main decomposition peaks. The first peak of around $353-370{ }^{\circ} \mathrm{C}$ and $373-376{ }^{\circ} \mathrm{C}$ referred to ash wood and black pine wood flour reinforced HDPE composites, respectively, while the second peak came from HDPE and was around $469-490{ }^{\circ} \mathrm{C}$. Residue after $500{ }^{\circ} \mathrm{C}$ was increased with the addition of wood concentration to HDPE matrix. The mass loss for the samples with both untreated ash and black pine wood flour at $500{ }^{\circ} \mathrm{C}$ was $93.8 \%$ and $92.6 \%$, respectively.

Table 3 Summary of thermal stability for neat HDPE and their composites

Tablica 3. Sažetak rezultata toplinske stabilnosti čistog HDPE-a i kompozita

\begin{tabular}{|c|c|c|c|c|c|}
\hline Samples / Uzorci & $T 10 \%,{ }^{\circ} \mathrm{C}$ & $T 50 \%,{ }^{\circ} \mathrm{C}$ & $T 90 \%,{ }^{\circ} \mathrm{C}$ & DTGmax, ${ }^{\circ} \mathrm{C}$ & Weight loss, \% / Gubitak mase, \% \\
\hline HDPE & 449 & 481 & 499 & 491 & 99 \\
\hline UAC3 & 303 & 441 & 493 & 486 & 94 \\
\hline TAC3 & 356 & 475 & 503 & 489 & 95 \\
\hline UBPC3 & 306 & 451 & 494 & 487 & 93 \\
\hline TBPC3 & 343 & 476 & 511 & 490 & 95 \\
\hline
\end{tabular}




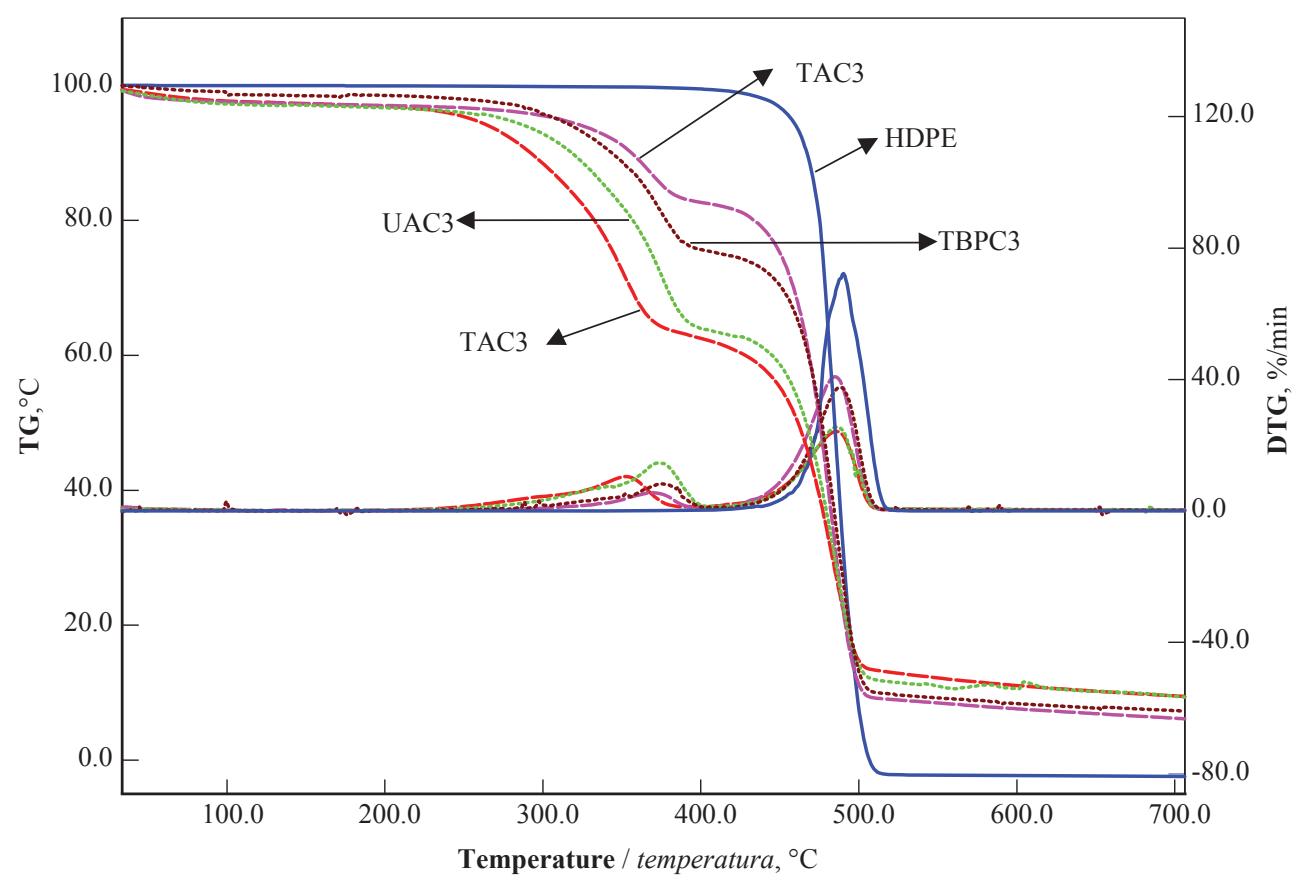

Figure 1 TGA results of wood reinforced HDPE composites

Slika 1. TGA rezultati drvom ojačanih HDPE kompozita

Figure 1 also shows that the samples with untreated ash wood and heat-treated black pine wood flour exhibited higher thermal stability as compared to the samples with the heat-treated ash and untreated black pine wood flour. Thermal stability of the composites produced from heat-treated wood increased. The increase could also be attributed to better adhesion between wood and the matrix (HDPE) because the pretreatment possibly lowered the polarity of wood and made wood more compatible with the matrix. Similar results were also reported by Li et al. (2013).

Morphology of the untreated/heat-treated ash and black pine wood flour reinforced HDPE composites was also studied. SEM micrographs of neat HDPE, the samples with $30 \%$ untreated ash and heattreated ash wood flour, and the samples with $30 \%$ untreated black pine and heat-treated black pine wood flour are given in Figure 2. Fractured surface of neat HDPE is presented in Figure 2a. Furthermore, neat HDPE exhibits ductile mode of failure. Figure $2 b$ and $2 \mathrm{c}$ shows the wood fillers and their size in the samples with the heat-treated and untreated ash wood flour. The mode of failure becomes more brittle with HDPE composites with untreated wood (Ghasem, 2013; Atli et al., 2018). In addition, the surfaces of the composites with untreated wood have prominent holes due to particle pull out resulting from poor adhesion (Figure $2 \mathrm{~b}$ and 2d) (Mengeloglu and Karakus, 2012). Under tensile stress, the particles were easily pulled out from the matrix. This may mean that the interface could not effectively transfer the stress. This observation is in agreement with the lower modulus values recorded for the untreated wood composites (Table 2). Furthermore, for the heat-treated ash and black pine wood flour reinforced composites (Figure 2d and 2e), the holes are not quite prominent and particles pull out appears relatively less compared to the untreated ones. The particle surface is slightly rough and nearly uniformly dispersed and embedded within the matrix. Similar results for untreated and heat-treated wood reinforced HDPE composites were also reported by Arwinfar et al. (2016) and Aragal et al. (2012).

\subsection{XRD Analysis of neat HDPE and wood reinforced HDPE polymer composites}

3.3. XRD analiza čistog HDPE-a i drvom ojačanih HDPE kompozita

X-ray diffractograms of HDPE and its composites are presented in Figure 3. Neat HDPE and its composites showed peaks around $2 \theta=22.1^{\circ}$ and $24.50^{\circ}$. The peaks for the (110) and (200) planes of HDPE shifted little when the wood flour was added and an important change in the diffraction peak intensity was not observed with the presence of wood flour.

Crystallinity index $(C I)$ of neat HDPE and its composites was calculated with XRD peaks. With the addition of wood flour, the $C I$ changed in all the XRD. $C I$ was calculated as $61.2 \%$ for neat HDPE, $41.6 \%$ for untreated ash wood flour reinforced HDPE polymer composites (UAC3), $44.8 \%$ for heat treated ash wood flour reinforced HDPE composites (TAC3), $43.9 \%$ for untreated black pine wood reinforced HDPE composites (UBPC3), and $46.2 \%$ for heat treated black pine wood reinforced HDPE composites (TBPC3). It was determined that crystallinity of cellulose in wood increased with thermal modification. It is believed that mechanical properties of wood flour reinforced HDPE composites had a positive effect due to high crystallinity properties of polymer composites manufactured with heat treated wood. After thermal modification of wood at high temperature (at $180{ }^{\circ} \mathrm{C}$ and above), the 


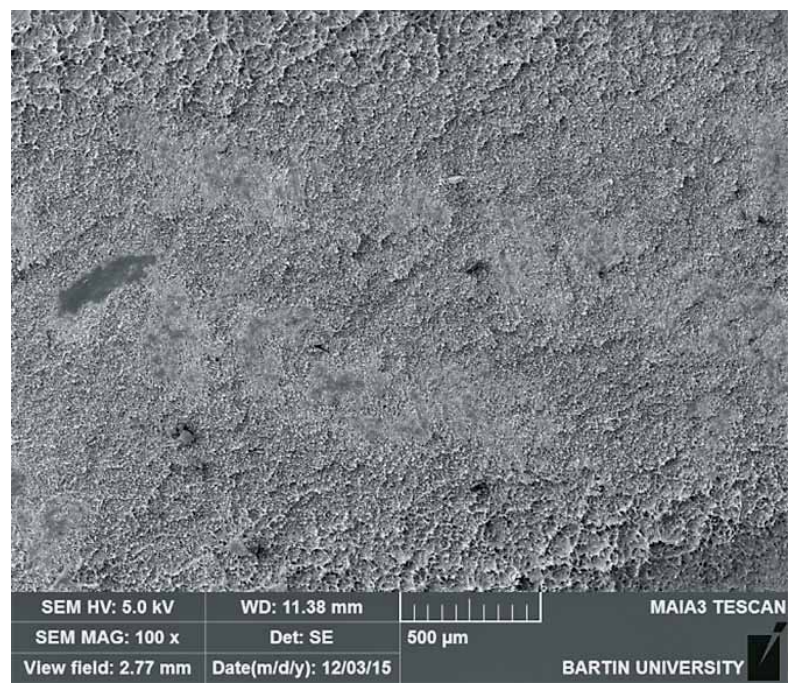

a)
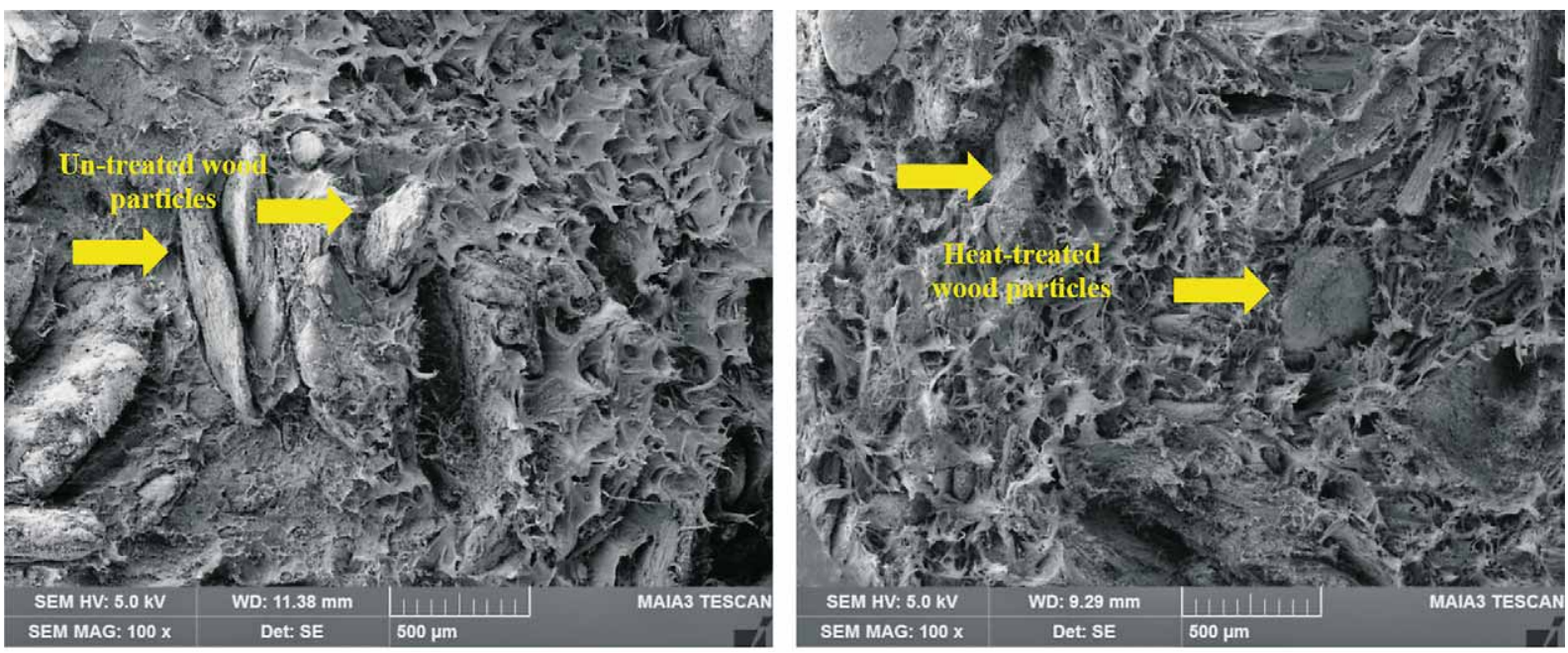

b)

c)
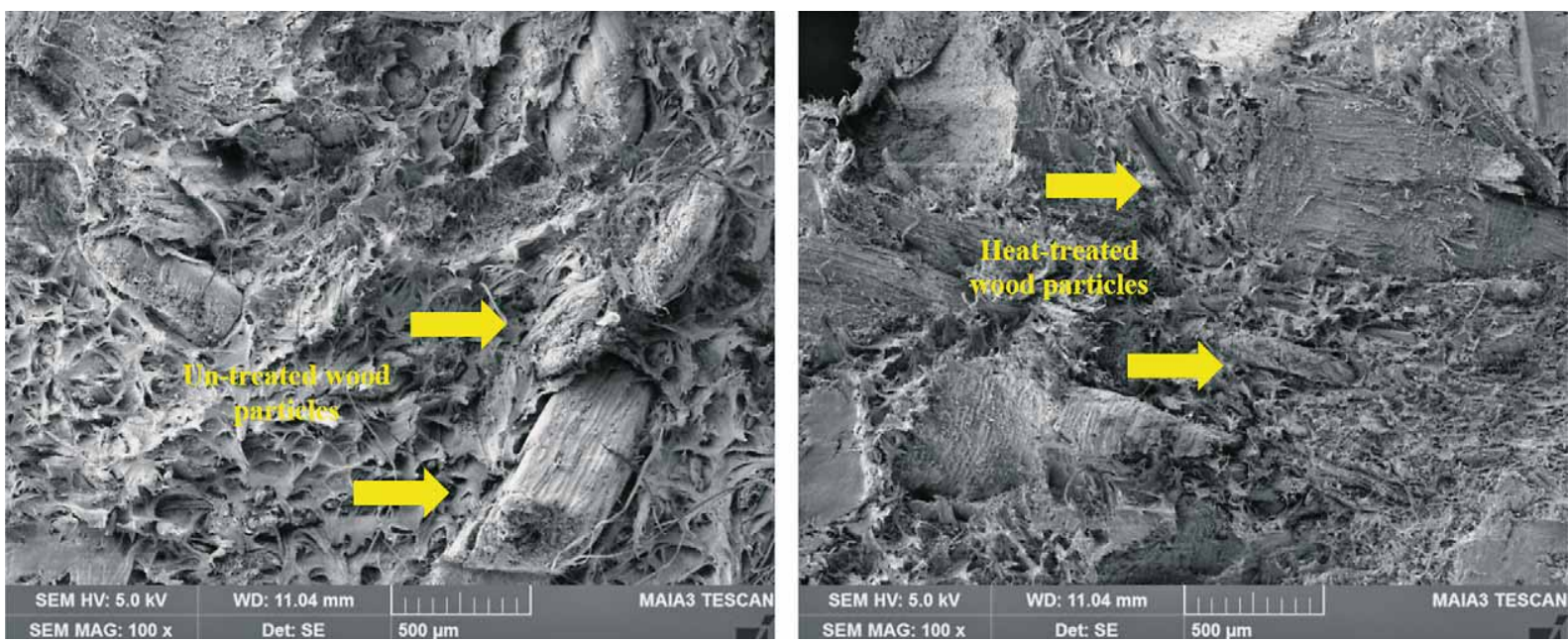

e)

Figure 2 SEM micrographs of (a) neat HDPE, (b) untreated ash (UAC3), (c) heat treated ash (TAC3), (d) untreated black pine (UBPC3), (e) heat treated black pine (TBPC3)

Slika 2. SEM mikrografije (a) čistog HDPE-a, (b) nemodificiranog drva ariša (UAC3), (c) toplinski modificiranog drva ariša (TAC3), (d) nemodificiranog drva crnog bora (UBPC3), (e) toplinski modificiranog drva crnog bora (TBPC3)

crystallinity ratio of the heat-treated wood increased slightly due to the degradation of the hemicelluloses and the crystallinity ratio of softwood was found to increase more in comparison with hardwood (Aydemir et al., 2015). Consequently, it can be said that the crys- tallinity of black pine wood increased with thermal modification more than that of ash wood and, therefore, the effect of pine wood on the mechanical properties of the composites was determined to be higher than that of ash wood. 


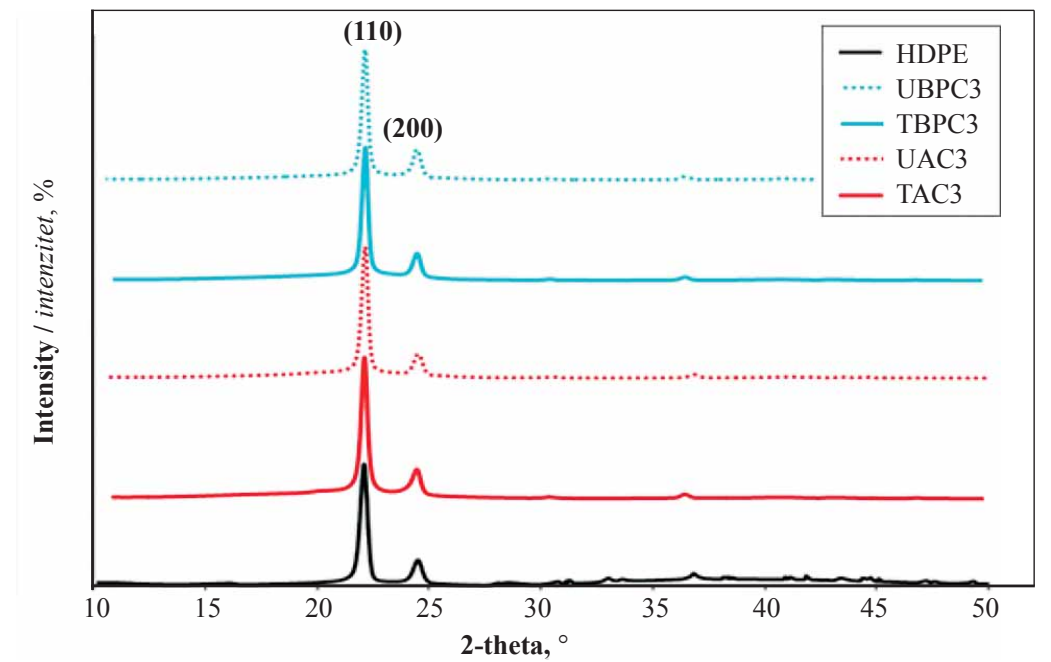

Figure 3 X-ray diffractograms of HDPE and its composites Slika 3. Rendgenski difraktogrami HDPE-a i kompozita

\section{CONCLUSIONS}

\section{ZAKLJUČAK}

This study evaluated the effect of untreated and heat-treated ash and black pine wood flour concentrations on the physical, mechanical, thermal and morphological properties of HDPE composites. Physical properties (density), mechanical properties (tensile, flexural, impact strength and hardness), thermal properties (TGA) and morphological properties (SEM) were determined. According to the obtained results, mechanical properties of all HDPE composites were found to be lower than those of neat HDPE. Statistical analysis showed that density, flexural strength, flexural modulus tensile modulus and hardness values of polymer composites significantly increased with the rising percentages of ash and black pine wood flour. Both heat-treated ash and black pine wood flour reinforced HDPE composites had a positive effect on hardness. Heat-treated ash and black pine wood flour reinforced HDPE composites had a positive effect on mechanical properties compared to untreated ones. The increase in wood concentration improved flexural strength, tensile modulus, flexural modulus and hardness while reducing tensile strength, elongation at break and impact strength. However, impact strength values of HDPE composites produced from heat-treated ash and black pine wood flours were slightly lower. Heat treatment had a negative effect on impact strength. HDPE showed single stage degradation while both ash and black pine wood flour reinforced HDPE composites showed a two-step mass loss thermal degradation. The first peak of around $353-370{ }^{\circ} \mathrm{C}$ and $373-376{ }^{\circ} \mathrm{C}$ referred to ash wood and black pine wood flour reinforced HDPE composites, respectively, while the second peak came from HDPE and was around $469-490{ }^{\circ} \mathrm{C}$. Residue after $500{ }^{\circ} \mathrm{C}$ was increased with the addition of wood concentration to HDPE matrix. The crystallinity of the composites with heat-treated wood was found to be higher than that of untreated wood-HDPE composites according to the data obtained with XRD. According to the study results, it can be concluded that heat-treated wood flour can be used as an alternative raw material in the application areas of wood-HDPE composites.

\section{Acknowledgements - Zahvala}

Authors would like to thank Prof. Dr. M. Hakk1 ALMA for hardness testing.

\section{REFERENCES}

\section{LITERATURA}

1. Alsewailem, F. D.; Binkhder, Y. A., 2014: Effect of coupling agent on the properties of polymer/date pits composites. Journal of Composites Article, ID 412432. https://doi.org/10.1155/2014/412432.

2. Aragal, R. A.; Hassan, A.; Yahya, R.; Rahman, N. A.; Hornsby, P. R.; Heidarian, J., 2012: Thermal and mechanical properties of treated and untreated Red Balau (Shorea dipterocarpaceae) / LDPE composites. Journal of Reinforced Plastics and Composites, 31 (4): 215-224. https://doi.org/10.1177\%2F0731684411433913.

3. Arwinfar, F.; Hosseinihashemi, S. K.; Latibari, A. J.; Lashgari, A.; Ayrilmis, N., 2016: Mechanical properties and morphology of wood plastic composites produced with thermally treated beech wood. BioResources, 11 (1): 1494-1504.

https://doi.org/10.15376/biores.11.1.1494.

4. Atli, A.; Candelier, K.; Alteyrac, J., 2018: Mechanical, thermal and biodegradable properties of bioplast-spruce green wood polymer composites. International Journal of Chemical, Materials and Biomolecular Science, 12 (5): 231-243. https://doi.org/10.5281/zenodo.1317160.

5. Aydemir, D.; Alsan, M.; Altuntas, E.; Oztel, A., 2019: Mechanical, thermal and morphological properties of heat-treated wood-polypropylene composites and comparison of the composites with PROMETHEE method. Plastics, Rubber and Composites, 48: 389-400. https://doi.org/10.1080/14658011.2019.1638132.

6. Aydemir, D.; Kiziltas, A.; Kiziltas, E.; Gardner, D. J.; Gunduz, G., 2015: Heat treated wood-nylon 6 composites. Composites: Part B, 68: 414-423. https://doi.org/10.1016/j.compositesb.2014.08.040.

7. Boonstra, M. J.; Van Acker, J.; Tjeerdsma, B. F.; Kegel, E. V., 2007: Strength properties of thermally modified softwoods and its relation to polymeric structural wood 
constituents. Annals of Forest Science, 64 (7), 679-690. https://doi.org/10.1051/forest:2007048.

8. Borůvka, V.; Zeidler, A.; Holeček, T., 2015: Comparison of stiffness and strength properties of untreated and heattreated wood of douglas fir and alder. BioResources, 10 (4): 8281-8294.

https://doi.org/10.15376/biores.10.4.8281-8294.

9. Byren, C. E.; Nagle, D. C., 1997: Carbonization of wood for advanced materials applications. Carbon, 35: 259266. https://doi.org/10.1016/S0008-6223(96)00136-4.

10. Cetin, N. S.; Ozmen, N., 2011: Acetylation of wood components and fourier transform infra-red spectroscopy studies. African Journal of Biotechnology, 10 (16): 30913096. https://doi.org/10.5897/AJB10.2630.

11. Donmez Cavdar, A.; Mengeloglu, F.; Karakus, K., 2015: Effect of boric acid and borax on mechanical, fire and thermal properties of wood flour filled high density polyethylene composites. Measurement, 60: 6-12. https://doi.org/10.1016/j.measurement.2014.09.078.

12. Donmez Cavdar, A.; Mengeloglu, F.; Karakus, K.; Dizman Tomak, E., 2014: Effect of chemical modification with maleic, propionic, and succinic anhydrides on some properties of wood flour filled HDPE composites. BioResources, 9 (4): 6490-6503. https://doi.org/10.15376/biores.9.4.6490-6503.

13. Follrich, J.; Muller, U.; Gindl, W.; Mundigler, N., 2010: Effects of long-term storage on the mechanical characteristics of wood plastic composites produced from thermally modified wood fibers. Journal of Thermoplastic Composite Materials, 23 (6): 845-853. https://doi.org/10.1177\%2F0892705710369042.

14. Ghasem, J., 2013: Economic model assessment of woodpolymer composites production from agricultural wastes. Annals of biological research-Scholar research library, 4 (5): 169-174.

15. Gunduz, G.; Aydemir, D., 2009: The influence of mass loss on the mechanical properties of heat-treated black pine wood. Wood Research, 54 (4): 33-42.

16. Hua, J.; Zhao, Z.; Yu, W.; Wei, B., 2011: Hydroscopic and mechanical properties performance analysis of rice husk powder/PLA composites. Advanced Materials Research, 230 (232): 1231-1235. https://doi.org/10.4028/ www.scientific.net/AMR.230-232.1231.

17. Huang, H. B.; Du, H. H.; Wang, W. H.; Wang, H. G., 2012: Effects of the size of wood flour on mechanical properties of wood-plastic composites. Advanced Materials Research, 393-395: 76-79.

https://doi.org/10.4028/www.scientific.net/AMR.393-395.

18. Kabir, M. M.; Wang, H.; Lau, K. T.; Cardona, F., 2012: Chemical treatments on plant-based natural fibre reinforced polymer composites: An overview. Composites: Part B, 43 (7): 2883-2892. https://doi.org/10.1016/j.compositesb.2012.04.053.

19. Kaboorani, A.; Faezipour, M., 2009: Effects of wood preheat treatment on thermal stability of HDPE composites. Journal of Reinforced Plastics and Composites, 28 (24): 2945-2955. https://doi.org/10.1177\%2F0731684408094064.

20. Kaboorani, A.; Faezipour, M.; Ebrahimi, G., 2008: Feasibility of using heat treated wood in wood/thermoplastic composites. Journal of Reinforced Plastics and Composites, 1689-1699. https://doi.org/10.1177\%2F0731684407084207.

21. Karakus, K.; Birbilen, Y.; Mengeloglu F., 2016: Assessment of selected properties of LDPE composites reinforced with sugar beet pulp. Measurement, 88: 137-146. https://doi.org/10.1016/j.measurement.2016.03.039.
22. Kaymakc1, A.; Ayrılmıs, A.; Ozdemir, F.; Gulec, T., 2013: Utilization of sunflower stalk in manufacture of thermoplastic composite. Journal of Polymer. Environment, 21 (4): 1135-1142.

https://doi.org/10.1007/s10924-012-0564-9.

23. Kellogg, R. M., 1981: Physical properties of wood. In: Proceedings of Wood: its structure and properties (ed. F. F. Wangaard). Pennsylvania State University, College Park, PA, pp. 191-223.

24. Kiziltas, A.; Gardner, D. J.; Han, Y.; Yang, H. S., 2014: Mechanical properties of microcrystalline cellulose (MCC) filled engineering thermoplastic composites. Journal of Polymers and the Environment, 22 (3): 365372. https://doi.org/10.1007/s10924-014-0676-5.

25. Kord, B., 2011: Effect of wood flour content on the hardness and water uptake of thermoplastic polymer composites. World Applied Sciences Journal, 12 (9): 1632-1634.

26. Li, Y.; Du, L.; Kai, C.; Huang, R.; Wu, Q., 2013: Bamboo and high density polyethylene composite with heat-treated bamboo fiber: thermal decomposition properties. BioResources, 8 (1): 900-912. https://doi.org/10.15376/biores.8.1.900-912.

27. Medupin, R. O.; Abubakre, O. K.; Ukoba, K. O.; Imoisili, P. E., 2013: Mechanical properties of wood waste reinforced polymer matrix composites. American Chemical Science Journal, 3 (4): 507-513.

https://doi.org/10.9734/ACSJ/2013/5637.

28. Mengeloglu, F.; Karakus, K., 2008: Thermal degradation, mechanical properties and morphology of wheat straw flour filled recycled thermoplastic composites. Sensors, 8 (1): 500-519. https://doi.org/10.3390/s8010500.

29. Mengeloglu, F.; Karakus, K., 2008a: Some properties of eucalyptus wood flour filled recycled high density polyethylene polymer-composites. Turkish Journal of Agriculture and Forestry, 32(6): 537-546.

30. Mengeloglu, F.; Karakus, K., 2012: Mechanical properties of injection-molded foamed wheat straw filled HDPE biocomposites: the effects of filler loading and coupling agent contents. BioResources, 7 (3): 3293-3305.

31. Obasi, H. C., 2015: Peanut husk filled polyethylene composites: effects of filler content and compatibilizer on properties. Journal of Polymers Article, ID 189289. https://doi.org/10.1155/2015/189289.

32. Ozmen, N.; Cetin, N. S.; Mengeloglu, F.; Birinci, E.; Karakus, K., 2013: Effect of wood acetylation with vinyl acetate and acetic anhyride on the properties of woodplastic composites. BioResources, 8 (1): 753-767. https://doi.org/10.15376/biores.8.1.753-767.

33. Rabiej, M., 2003: Application of the genetic algorithms and multi-objective optimization to the resolution of XRay diffraction curves of semi crystalline polymers. Fibers Textiles, 11: 83-87.

34. Robin, J. J.; Breton, Y., 2001: Reinforcement of recycled polyethylene with wood fibers heat treated. Journal of Reinforced Plastics and Composites, 20: 1253-1262. https://doi.org/1177/073168401772679183.

35. Rosa, S. M. L.; Santos, E. F.; Ferreira, C. A.; Nachtigall, S. M., 2009: Studies on the properties of rice husk filled PP composites. Materials Research, 12 (3): 333-338. http://dx.doi.org/10.1590/S1516-14392009000300014.

36. Sathishkumar, T. P., 2014: Comparison of Sansevieria ehrenbergii fiber-reinforced polymer composites with wood and wood fiber composites. Journal of Reinforced Plastics and Composites, 33 (18): 1704-1716. https://doi.org/10.1177\%2F0731684414542991.

37. Segerholm, K., 2012: Characteristics of wood plastic composites based on modified wood-moisture properties, 
biological resistance and micromorphology. Doctoral thesis. KTH Building Materials Technology, Stockholm.

38. Shi, J. L.; Kocaefe, D.; Zhang, J., 2007: Mechanical behaviour of Quebec wood species heat-treated using thermowood process. Holz als Roh- und Werkstoff, 65 (4): 255-259. https://doi.org/10.1007/s00107-007-0173-9.

39. Simpson, W.; TenWolde, A., 1999: Physical properties and moisture relations of wood, Chapter 3. The Wood Handbook: Wood as an Engineering Material, General Technical Report, FPL-GTR-113, USDA Forest Service, Forest Product Laboratory, Madison WI, USA, p. 2.1-2.4.

40. Tisserat, B.; Reifschneider, L.; Joshee, N.; Finkenstadt, V. L., 2013: Properties of high density polyethylene-Paulownia wood flour composites via injection molding. BioResources, 8 (3), 4440-4458.

41. Yang, H. S.; Wolcott, M. P.; Kim, H. S.; Kim, H. J., 2005: Thermal properties of lignocellulosic filler-thermoplastic polymer bio-composite. Journal of Thermal Analysis and Calorimetry, 82 (1): 157-160. https://doi.org/10.1007/s10973-005-0857-5.

42. Yildiz, S.; Gezer, E. D.; Yildiz, U. C., 2006: Mechanical and chemical behavior of spruce wood modified by heat. Building and Environment, 41 (12): 1762-1766. https://doi.org/10.1016/j.buildenv.2005.07.017.

43. ***ASTM D2240-15e1, 2015: Standard test method for rubber property - Durometer hardness, ASTM International, West Conshohocken, PA.
44. ***ASTM D256-10, 2018: Standard test methods for determining the izod pendulum impact resistance of plastics, ASTM International, West Conshohocken, PA.

45. ***ASTM D638-14, 2014: Standard test method for tensile properties of plastics, ASTM International, West Conshohocken, PA.

46. ***ASTM D790-17, 2017: Standard test methods for flexural properties of unreinforced and reinforced plastics and electrical insulating materials, ASTM International, West Conshohocken, PA.

47. ***ASTM D792-13, 2013: Standard test methods for density and specific gravity (relative density) of plastics by displacement, ASTM International, West Conshohocken, PA.

\section{Corresponding address:}

\section{DENIZ AYDEMIR}

Bartin University

Faculty of Forestry

Department of Forest Industrial Engineering 74100, Bartin, TURKEY

e-mail: denizaydemir@bartin.edu.tr 